\title{
SHIFTING PERCEPTIONS OF BLACK STUDENTS IN A SOUTH AFRICAN UNIVERSITY RESIDENCE
}

\author{
S. Vandeyar \\ Department of Humanities Education \\ University of Pretoria Groenkloof Campus \\ Pretoria, South Africa \\ e-mail: saloshna.vandeyar@up.ac.za
}

\author{
A. Mohale \\ Umalusi \\ Pretoria, South Africa \\ e-mail: agnes.mohale@yahoo.com
}

\section{ABSTRACT}

Utilising the methodology of portraiture this qualitative case study set out to understand how students from different racial and ethnic backgrounds interpret their own experiences as they shared their personal space in a university residence with people who had previously been seen as the out-group. Data capture included semi-structured interviews, observations, and field notes. Theoretical moorings of this study were critical race theory and contact theory. Data was analysed by means of content analysis. Findings of this study reveal that contact between diverse students helped to reduce prejudices thus changing pre-conceived student perceptions.

Keywords: students, university residence, race, interaction, perceptions, South Africa

\section{INTRODUCTION}

In his book Knowledge in the Blood Jansen (2009) gives an account of a memory from his apartheid past. The memory emanates from encounters that influenced his early perceptions of white Afrikaans-speaking South Africans. It began with among others the legacy of the Group Areas Act of 1950 which according to Jansen (2009) was responsible for the forceful removal of his grandparents from their land. He maintains that because of the knowledge he accumulated on how his family had lost their property, he carried with him anger and hostility towards white Afrikaans-speaking South Africans. As the narrative unfolds Jansen (2009) recollects an incident during which he was attacked by a white boy while walking in the street. An attempt to defend himself led to assault by the boy's father and the possibility of a further beating at the local police station. Likewise, the knowledge that Jansen possessed about how the police dealt with activists and Black people made him shiver. Many years later Jansen, the then Dean at a 
historically white Afrikaans university, was addressing white Afrikaans-speaking school girls. As he concluded his story he revealed:

So you see I too have this terrible knowledge of what happened to me, and all my life I have been struggling to cross this bridge towards people who look like you. And I must be honest it is difficult (Jansen 2009, 93).

In South Africa perceptions, similar to what is observed in the narrative by Jansen (2009) are ingrained in a number of segregation policies which formerly prohibited interracial mixing during the apartheid era. Among others the Group Areas Act of 1950 and the Extension of University Act of 1959, which barred historically white universities from accommodating students of other racial groups (Greyling 2007; Finchilescu and Tredoux 2010) and witnessed the establishment of universities in various homelands ${ }^{1}$ (Anderson 2003). Because of this exclusionary practice, contact between students from different races was limited in South African universities.

Various institutions in the new dispensation in South Africa had to modify their policies to respond to the demands of transformation as prescribed by legislation. Transformation implies that there should be changes in the structures, institutional policies, arrangements and relationships within society (Ramphele 2008) which aims at disbanding the existing social standings and establishments so as to create something new (Badat 2009). Accordingly, South African universities also had to undergo transformation. Thus, people who were intentionally segregated during the apartheid era are now brought together at institutions of learning and in other contexts.

South Africa has made some progress in terms of democratic practices, but there are still many challenges in terms of integration. Contact between different races is still shallow (Finchilescu et al. 2007). These challenges bring South African university residences into the spotlight as administrators strive to make students who were formerly segregated by the apartheid regime share their personal spaces. Knowledge of the past which is characterised by stereotypes, discrimination and racism may pose challenges to diverse students at universities, who attempt to transgress the legacy of apartheid in order to begin reconstructing fresh perceptions of one another. Accordingly, this study asks: How has staying at a multiracial South African university residence influenced the perceptions of black students?

\section{RACE RELATIONS AT UNIVERSITIES}

Racism during the apartheid era in South Africa was expressed both as biological and social constructs (Gilroy 2000; Essed 2002). The architects of apartheid used differences not only of 
skin pigmentocracy and physical attributes but also of language, nationality, and religion to socially construct a society based on an apartheid ideology. The early years of democracy in South Africa were characterised by a sense of euphoria as the ideals contained in the Constitution provided all citizens with equal opportunities. In everyday and institutional life however, race categories continue to operate and is also expressed in continued experiences of racism (Essed 2002).

A review of the international literature reveals that there are a few findings that report on positive interracial experiences of Black students at universities. These take the form of intergroup friendships and how this is linked to important outcomes such as reduced prejudice, increased empathy for out-groups, and lower intergroup anxiety (Schofield et al. 2007), interracial roommate relationships and its benefits (Shook 2007), cross-group friendships and cues of social connectedness to an out-group member (Brannon and Walton 2013) and intergroup contact related to participants engagement in cross-race relationships (Edmonds and Killen 2009). However, the majority of findings in the international literature reveal that contact between black and white students yields negative rather than positive experiences for black students (Smith, Allen and Danley 2007). Most black students are aware of the negativity that white people feel towards them (Livingstone 2002). In some instances this awareness of racism and discrimination has led to 'cultural mistrust' which propelled the fear of intergroup contact (Soto, Dawson-Andoh and BeLue 2011). Peer prejudice remained of great concern for black students and led to anxiety (Fisher, Wallace and Fenton 2000). Black students were found to be more susceptible to the effects of stereotype expectation (Chavous et al. 2004). Negative race relations between Blacks and whites in historically white universities led to some black students transferring to historically black universities (Read, Archer and Leathwood 2003) and encouraged black students to self-segregate and further to create social counter spaces (Solorzano, Ceja and Yosso 2000).

For some black students, the negative experiences they experienced heightened their awareness of marginality and exclusion and they consequently harboured hostility towards other races (Johnson 2003). The tendency to put constraints on how far some students were willing to interact with diverse students was evidence by their reluctance to share rooms with those of a different race or culture (Johnson 2003). There were instances in which explicit racism could be detected amongst student interactions in some university residences. For example: racial insults written in elevators (Harwood, Huntt and Mendenhall 2009), white students treated badly by other white students for interacting with black students (Lorenz 2009), graffiti that expressed racism and flags hanging from a residence window written 'Niggers go 
home' (Davis, Dias-Bowie and Geenberg 2004). Black students reported experiences of interpersonal insensitive comments, staring or rude behaviour (Swim et al. 2003). These encounters of prejudice and discrimination placed emotional strain and discomfort on some black students when they were around their white counterparts (Swim et al. 2003).

Findings from studies conducted in the South African context reveal that the dynamics of a lack of interaction between Blacks and whites that was observed in the broader society is also evident among university students (Sennet et al. 2003). Most studies conducted in this field in the South African context document negative interactions between diverse students at South African universities (Moguerane 2007; Van der Merwe 2009). Some studies revealed that many black students did not desire more interracial contact and they separated themselves to form predominantly black groups (Johnston, Wilson and Burgess 2004). There seems however to be a dearth of information regarding studies that explore best practices at university residences where black and white students experienced positive interactions.

\section{THEORETICAL MOORINGS}

Two theoretical underpinnings are used to frame the argument of this article namely, critical race theory (CRT) and contact theory. CRT provides a theoretical framework through which individually and institutionally motivated racist acts can be highlighted, critiqued, and corrected (Tyson 2003). CRT highlights two primary types of racism: individual and institutional racism. CRT pivots on four primary tenets. First, it rejects claims towards neutrality, objectivity, colorblindness, and meritocracy, arguing that these notions systematically devalue Blackness and Brownness by privileging and normalizing Whiteness. Second it asserts that racism is an embedded and institutionalized facet of society and, thus, is found at the core of its political, economic, and social structures. Third, it argues that liberalism has been and always will be, at best, a band-aid type of approach to remedy civil rights-oriented injustices. And, fourth, it uses autobiography and autobiographical narrative, by and/or about people of colour, to discuss larger societal issues (Delgado and Stefancic 2001).

Contact theory highlights four conditions that are conducive to successful inter-group contact namely, equal status within the situation, common goals, inter-group cooperation and support of authority (Allport 1954). This theory proposes that cross racial contact will produce more tolerant attitudes when members of different groups interact with each other on equal status and they are provided with equal opportunities to share power (Pettigrew 2008). It is not easy to accomplish equal status when different groups are battling for power to the extent that it creates conflicts for the entire desegregated group. Pettigrew (2008) argues that members of 
different groups should believe that their groups are meeting on equal status. The contact must be close enough to lead to perceptions of common interests and humanity amongst the group members and sanctioned by institutional support (Antonio et al. 2004; Tropp and Pettigrew 2005). Institutional policies may be structured around developing interventions that promote and ensure that positive intergroup contact is sustained (Pearson et al. 2008).

\section{RESEARCH STRATEGY}

This article reports on a slice of the data of a broader study that set out to understand how students from different racial and ethnic backgrounds interpret their own experiences as they shared their personal space with people who had previously been seen as the out-group. The sample of the broader study comprised of eight participants. This article offers detailed insight into two young Black women's views. Meta-theoretically we were drawn to the tenets that govern social constructivism as our worldview. Methodologically the lens we utilised identifies our view as qualitative inquirers, implementing the method of portraiture that intentionally sets out in 'search for goodness' (Lawrence-Lightfoot 1986, 14). The research design was qualitative in nature and utilised the narrative method and case study approach.

The case for the study was defined by a single university residence called EquityRes, an integrated student residence at Urban University. This residence was distinct from other residences because of the balance in its racial composition and unique living program. EquityRes which was established in 2008 comprises of ten four-story buildings. Each floor has two units and each unit has eight bedrooms, a communal bathroom, toilet facilities, a kitchen and a living space. EquityRes was designed in a manner to create a country atmosphere within a bustling city environment and to challenge not only the design but also the culture, traditions and ethos of traditional university residences. Residents at EquityRes are not compelled to participate in traditionally organised sport, cultural or other formalised activities. The residences have been designed to foster a community of scholars who have freedom of choice in terms of participation in sport and cultural activities. Six hundred and forty students are accommodated at this residence, of whom three hundred and twenty are male and the other three hundred and twenty female. The residence itself is co-educational but each unit is either occupied by males or females. A unit consists of eight rooms, which is intentionally allocated to four white students and four black students to foster racial integration and racial parity.

This research site was selected because of its potential to provide a sample that fit the description of an exemplary constituent. Purposeful sampling was employed. The sample comprised four black females and four white females from one unit. A decision was made to 
sample a unit of senior students who had in-depth experience of the phenomenon under study and had already acquired a wealth of information about the case; and had the ability to effectively express their experiences (Ponterotto and Grieger 2007).

Data capture included a mix of semi-structured interviews, document analysis, observations and field notes. Semi-structured interviews were the main method of data collection and were approximately an hour long in duration. Follow-up interviews provided the opportunity for member checking and adding of information. Content analysis method was used to analyse the data.

\section{FINDINGS}

\section{Kgadi: 'I thought that they were all the same. They were racist'}

Kgadi revealed that as a young child she stayed in a black township but moved to a white suburb while she was still at primary school. Her narrative revealed that race did not determine boundaries for young children.

... race amongst kids really doesn't matter. They just see you as a person. I also saw them that way. I didn't go like; oh! I have a white friend. I just saw I had a friend. As I grew up, I saw that there are racial differences.

She recalled her mother was very open to her having a friend from another country. She welcomed it and found it interesting. She remembered her mother remarking 'Oh, you have a white friend.'

However, by the time Kgadi wanted to enrol at a historically Afrikaans university her mother changed her views. In this respect racism was a major concern. Her mother and grandmother held strong negative perceptions about white people whom they associated with discrimination and racism.

My mom was very anti Afrikaans, as much as she loved this university, Before I even got to EquityRes my mom and people around me already told me, 'You know EquityRes is very racist'. They are going to call you on the radio and you will be forced to sing Afrikaans songs.

Kgadi expressed that she did not want to be in a residence where cultural and linguistic capital awarded power and status,

I was allocated to another residence called Meisielaan. I went to check the room out. When I arrived at the residence, there were these black girls singing Afrikaans songs in a line and they had to dance and stuff before they could enter. I was like No! No! No! I didn’t even go to the room. 
However, her initial perceptions of white people began to change with her exposure at EquityRes.

They are really teaching me to be open-minded you know, not be judgemental and stuff like that. Just to be like friendly, there is no need for stereotypes or the way you think people are or a certain person is, doesn't mean now you have to treat everyone like that.

She began to attach value to lessons she learned at EquityRes. She did not only attribute the benefits to how she related with white people, but also to how she interacted with the human beings in general.

I think I have benefited even like amongst ... not only whites you know I have learned to be openminded and accept other people. Like people in general, you can't treat them the same because even amongst us as blacks, there is a lot of division.

Kgadi spoke strongly about how her discernment of white people changed.

In my first year, even before I came to EquityRes I was just negative. Each time I saw a white person on campus I just passed them and just thought in a certain way because of the mentality that I had from my parents. All of a sudden I have all these white people around me. EquityRes has changed that perception. I saw that all white people are not like that.

Staying at EquityRes helped Kgadi to work on her stereotypes. She acknowledged that being in close proximity with white people caused her to begin thinking about her own prejudices.

I thought that they were all the same. They were racist. That they are better, but engaging with them they have changed my perceptions. I don't think that they are better. They are just normal people. I used to think they all looked at black people as one thing. They actually see you as an individual. Like these girls notice when I change my hair, they always notice. I thought they just see... she braided.

\section{Mercy: 'So when I was able to drop that inferiority complex and just try and break through my comfort zone I found that it was all in my head'}

Mercy is one of five children and hails from one of the former homelands created during the apartheid era. She initially lived in a predominantly black township and later settled in a historically white suburb.

When we were growing up we knew all our neighbours and we interacted with them. In the suburb we are pretty much around white people ... our neighbours. It is very different because in the suburb people keep to themselves. So we really don't get to know our neighbours. It was just hi/bye situation, so ja, I felt the difference.

Her exposure to and experiences at EquityRes helped her to break through the racial barriers that limited her interaction with whites. 
I have learned to be much more comfortable around different races. I think it is definitely... in a small way without people even realising that being put together with different races, being forced to live with different races is going to ... in the future we are going to just be able to interact with different races more easily.

Upon her arrival at EquityRes Mercy only associated with black people as she did not know how to associate with white people. Staying at EquityRes offered Mercy a mirror through which she reflected on her perceptions and at the same time offered her a window to view and understand racial others.

... Growing up I was never really around other races except blacks. When you are walking around you see one white person it's like okay, I don't really know how to approach this person, even though they are just human beings. So when I was able to drop that and just try and break through my comfort zone I found that it was all in my head.

By breaking out of her comfort zone, she had learnt much about the white girls in her unit. She became aware of the difference between the two races in terms of social interactions. She broke through her own isolation and began to cross the bridge by interacting with people she previously regarded as the out-group.

On the black side we don't really talk that much. When you see the white girls, you find them in their rooms, all together, talking and getting to know each other. I tried to also just join them and see how it is. It was one night we were talking about everything, talking about their lives. I found that interesting because with the black girls ... we don't really ... it's more like, how is your day? They are just talking about everything you know, not really reserved.

\section{ANALYSIS AND DISCUSSION OF FINDINGS}

Several significant findings surfaced from this study. First, the two black participants brought preconceived perceptions to a historically white Afrikaans university. This was due to racial socialisation in the form of racial pride and racial barriers by peers, family members and the community (Hughes et al. 2006). Kgadi was discouraged by her mother, grandmother and other people around her when she wanted to study at Urban University. They made attempts to influence Kgadi's opinion about race relations because of their experiences of discrimination and racism during the apartheid era. Kgadi's family provided what Jansen (2009) referred to as 'reserves of social knowledge'. Her knowledge of racial discrimination was based on what her family transferred orally since she did not experience the atrocities of apartheid in person. It would seem that both her mother and grandmother who may have experienced individual and institutional racism were eager to reject claims of neutrality, objectivity, color-blindness and meritocracy. They tried to shield her from individual and institutional racism. It is worthwhile to emphasise that as a young child Kgadi experienced interracial contact but as she grew up she started becoming aware of racial differences thus limiting her contact with racial others. Perhaps 
Kgadi's awareness was awakened by the assertion made by CRT (Tyson 2003) that racism is an embedded and institutional facet of society. This finding seems to concur with earlier studies, for example, negative feedback about interracial contact (Crystal, Killen and Ruck 2008), warning about racist environment that black students might experience at historically white universities (Harper and Hurtado 2007; 2001) and the influence of stories of apartheid shared by family members on student perceptions (Vincent 2008).

The demographics of Mercy's initial neighbourhood led her to associate with black people. When she enrolled at Urban University she preferred to communicate with black students. This supports the findings of the study by Locks et al. (2008) who highlights that preuniversity demographics can affect interaction of diverse students. The fear of contact with white people was propelled by the fact that Mercy did not have prior experience of interracial contact in her previous environments. Her limited exposure to other racial groups could be attributed to the legacy of apartheid as the geographical demographics that defined her existence is still to a large extent contoured by racism and found at the core of economic and social structures. Mercy's dilemma echoes the findings of the study by Chavous et al. (2002) which revealed that black students who had limited contact with whites in their previous contexts might find it difficult to interact with white people. She was cautious to embrace the newfound liberalism which as CRT argues is at best, a band-aid type of approach to remedy civil rightsoriented injustices.

Second, black students avoided undesirable situations that confirmed the expected negative interactions with white students. Kgadi turned away from a university residence that she perceived as promoting the dominant white Afrikaans culture. She did not want to participate or be assimilated into the hegemonic traditions of an institution that was already tainted as discriminating and racist by her family. Kgadi exhibited what Soto, Dawson-Andoh and BeLue (2011) referred to as 'cultural mistrust'. She could not understand why black girls were made to perform activities that were typical of the culture of white Afrikaans-speaking people. It would seem that the 'traditional residences' at Urban University systematically devalued Blackness and Brownness by privileging and normalizing Whiteness, under the mask of perpetuating the history, culture and traditions of the institution. Kgadi's autobiographical narrative clearly indicated that racism was an embedded and institutionalised facet of the ‘traditional residences' of Urban University. Her vehement objection 'I was like No! No! No! I didn't even go to the room' could be interpreted in two ways: first, in terms of her 'reserves of knowledge' which affirmed her family's rejection of claims towards neutrality, objectivity, color-blindness and meritocracy. According to contact theory the conduct of people is 
influenced by their thoughts or experience of anxiety. Kgadi's negative thoughts seemed to have emanated from preconceived attitudes and knowledge about racial others. She seemed to be acutely aware that such seemingly harmless events such as singing a song are used to place students in positions of vulnerability. Second, and more importantly, her rejection and refusal to accept such averse practices. It would seem that Kgadi was an agent of change. What is admirable though is that Kagdi could so easily have slipped into stereotyping other racial groups given the 'reserves of knowledge' she got from her family and her awareness of traditional cultural practices of some of the other residences, yet, she did not. Instead she chose to stay at EquityRes where institutional policies were structured around developing interventions that promoted and ensured positive intergroup contact. She wanted to be afforded the opportunity and first-hand experience to meet members of different groups on equal status so that she could make up her own mind about inter-racial contact. She seemed eager to have close contact that could lead to perceptions of common interests and humanity amongst group members, and thus ultimately bring about social change.

Third, perceptions of the black participants about white students changed after staying at EquityRes. Kgadi realised that her perceptions of racial others should not be based on what she had learnt about them from her family. She had to learn to treat people as unique individuals and not as socially constructed categories. Her prejudices towards white people were reduced as she acknowledged that there was no need for her to treat people the same. Her stay at EquityRes afforded her experiences that rejected a band-aid type of approach to remedy civil rights-oriented injustices. It allowed her to live and interact with racial others within close personal spaces that fostered genuine interracial cooperation. According to Allport (1954) intergroup contact has the potential to produce more tolerant attitudes when members of different groups interact within certain conditions. Both Kgadi and Mercy acknowledged that continuous contact with the out-group helped them to transgress their racial barriers and to overcome their fear of interracial contact. Similarly, other studies embedded in contact theory found that people who previously had little contact with the out-group had demonstrated that more contact led to a change in attitude and they treated one another as individuals rather than as belonging to categories (Koehler and Skovoretz 2010; Tredoux et al. 2005). The perceptions of both Mercy and Kgadi changed as they were given the opportunity to meet all four conditions of contact theory namely, equal status within the situation, common goals, inter-group cooperation and support of authority. When diverse students lived together as equals, with support from the authority they had a chance to expand their knowledge of racial others (Saenz et al. 2007). Both participants in this study indicated that being able to interact with fellow 
students in their unit helped them to better understand and appreciate differences.

Fourth, the change in perception about white people helped the Kgadi and Mercy to interact better with people beyond EquityRes. Mercy expected to be comfortable around people of different races in the future. Kgadi learnt to be open-minded and to accept other people. Her intention to avoid stereotypes and prejudices was also extended to the way she should treat other black people as she acknowledged that differences also exist within the black group.

Findings of this study are in contrast with the findings of studies that reported negative experiences of black students in historically white universities (Moguerane 2007; Smith, Allen and Danley 2007; Van der Merwe 2009). Findings from this study seemed to suggest that EquityRes created a positive environment for interracial contact. EquityRes seemed to have taught Kgadi and Mercy to take cognisance of the differences and similarities between the two racial groups. Gill (2007) revealed that interacting with people of diverse backgrounds offered an opportunity for the out-group members to change their bias and prejudices. Kgadi and Mercy acknowledged that they came to EquityRes with negative preconceived perceptions about white people. They explained how their negative beliefs influenced them to avoid interracial contact when they initially arrived at Urban University. Consistent with the contact theory, perceptions of black students changed as they continued to live together with racial others at EquityRes.

\section{CONCLUSION}

Individual differences and societal norms shape intergroup contact effects (Pettigrew 1998). Given the historical context of South Africa it is refreshing to note that the 'born free generation'2 are moving towards positive interracial relationships and breaking the shackles of racial discrimination imposed on them by their parents and society at large. This study set out purposefully to utilise the methodology of portraiture and to look for 'goodness'; albeit in a small sample. A number of research studies in post-apartheid South Africa have adopted a pathological stance that tends to report on problems of racial discrimination and oppression at University residences (Msomi and Shilaho 2013; Jansen 2009; Moguerane 2007; Smith, Allen and Danley 2007). This study created an opportunity to view the dynamics of interactions between diverse students in a different light. Given the findings of this study the lack of contact in South African university residences can no longer be attributed solely to the differences in race or culture. In this study a change in perceptions towards racial others was reported by the two black participants. The autobiographical narratives of both participants seemed to suggest that they fellow white unit mates had also made some attempts to cross the bridge as evident from Mercy’s narrative.

When you see the white girls, you find them in their rooms, all together, talking and getting to know each other. I tried to also just join them and see how it is. It was one night we were talking 
about everything; talking about their lives ... they are just talking about everything you know, not really reserved.

The white girls accepted Mercy and allowed her to come into their room, a personal space and join them in conversation. Kgadi and Mercy both re-narrativized the globalisation story in an attempt to highlight, critique and correct individual and institutional motivated racist acts by placing historically marginalised parts of the world at the centre rather than the periphery of the education and globalisation debate and thus, ultimately brought about hope for social change.

As Jonathan Jansen concluded his speech before white Afrikaans speaking school girls he made a plea:

And so all I can ask of you is that you too try to cross the same bridge, from the other side, and maybe, just maybe, we will meet each other somewhere in the middle. For the sake of our country, we must at least try (Jansen 2009, 93).

\section{NOTES}

1. Homelands: an area reserved for occupation by Black African people, with limited self-government. In total, ten homelands were created in South Africa. These were Transkei, Bophuthatswana, Ciskei, Venda, Gazankulu, KaNgwane, KwaNdebele, KwaZulu, Lebowa, and QwaQwa. The homelands were designed for specific ethnic groups and that meant that whatever their culture was, they had to go to the given homeland. These homelands were abolished in 1993.

2. Born free generation: children born in South Africa from 1994 onwards.

\section{REFERENCES}

Allport, G. W. 1954. The nature of prejudice. Reading, MA: AddisonWesley.

Anderson, G. M. 2003. Racial identity, the apartheid state, and limit of political mobilisation and democratic reform in South Africa: The case of the University of the Western Cape. Identity: An International Journal of Theory and Research 3(1): 29-52.

Antonio, A. L., M. J. Chang, K. Hakuta, D. A. Kenny, S. Levin and J. F. Millem. 2004. Effects of racial diversity on complex thinking in college students. Psychological Science 15(8): 507-510.

Badat, S. 2009. Theorising institutional change: Post 1994 South African higher education. Studies in Higher Education 34(4): 455-467.

Brannon, T. N. and G. M. Walton. 2013. Enacting cultural interests: How intergroup contact reduces prejudice by sparking interest in an out-group’s culture. Psychology Science (10): 1947-57.

Chavous, T. M., A. Harris, D. Rivas, L. Helaire and L. Green. 2004. Racial stereotypes and gender in context: African Americans at predominantly black and predominantly white colleges. Sex Roles 51(1-2): 1-16.

Chavous, T., D. Rivas, L. Green and L. Helaire. 2002. Role of student background, perceptions of ethnic fit, and racial identification in the academic adjustment of African American students at a predominantly white university. Journal of Black Psychology 28(3): 234-260.

Crystal, D. S., M. Killen and M. Ruck. 2008. It is who you know that counts: Intergroup contact and judgments about race-based exclusion. The British Journal of Developmental Psychology 26(1): 51-70. http://doi.org/10.1348/026151007X198910

Davis, M., Y. Dias-Bowie and K. Geenberg. 2004. 'A fly in the buttermilk': Descriptions of university life by successful black undergraduate students at a predominantly white south-eastern university. The Journal of Higher Education 75(4): 420-445. 
Delgado, R. and J. Stefancic. 2001. Critical race theory: An introduction. New York: New York University Press.

Edmonds, C. and M. Killen. 2009. Do adolescents' perceptions of parental racial attitudes relate to their intergroup contact and cross-race relationships? Group Processes and Intergroup Relations 12(1): $5-21$.

Essed, P. 2002. Everyday racism. In Race critical theories, ed. P. Essed and D. Goldberg, 176-194. Oxford: Blackwell Publishers.

Finchilescu, G. and C. Tredoux. 2010. The changing landscape of intergroup relations in South Africa. Journal of Social Issues 66(2): 223-236.

Finchilescu, G., C. Tredoux, J. Pillay and Muianga. 2007. Accounting for lack of interracial mixing amongst South African university students. South African Journal of Psychology 3(4): 720-737.

Fisher, C. B., S. A. Wallace and R. E. Fenton. 2000. Discrimination distress during adolescence. Journal of Youth and Adolescence 29(6): 679-695.

Gill, S. 2007. Overseas students' intercultural adaptation as intercultural learning: A transformative work. A Journal of Comparative and International Education 37(2): 167-183.

Gilroy, P. 2000. Against race: Imaging political culture beyond the colour line. Harvard University Press, Massachusetts.

Greyling, S. A. 2007. Rhodes University during the segregation and apartheid eras, 1933-1990. Unpublished master's thesis. Rhodes University. Grahamstown.

Harper, S. R. and S. Hurtado. 2007. Nine themes in campus racial climates and implications for institutional transformation. In Responding to the realities of race on campus, ed. S. R. Harper and L. D. Patton. New Directions for Student Services, No. 120. San Francisco: Jossey-Bass.

Harwood, S., M. G. Huntt and R. Mendenhall. 2009. Racial micro-agressions and the University of Illinois at Urbana Champaign: Preliminary analysis of focus groups with students of color living in university housing. Centre on Democracy in a multiracial society. University of Illinois.

Hughes, D., J. Rodriguez, E. P. Smith, D. J. Johnson, H. Stevenson and P. Spicer. 2006. Parents' ethnic/racial socialization practices: A review of research and directions for future study.

Jansen, J. D. 2009. Knowledge in the blood. Cape Town: UCT Press.

Johnson, V. D. 2003. Cultural group perceptions of racial climates in residence halls. NASPA Journal 41(1): 114-134.

Johnston, R., D. Wilson and S. Burgess. 2004. School segregation in multi-ethnic England. Ethnicities 4(2): 237-265.

Koehler, G. and J. Skovoretz. 2010. Residential segregation in university housing: the mathematics of preferences. Social Science Research 39: 14-24.

Lawrence-Lightfoot, S. 1986. On goodness in schools: Themes of empowerment. Peabody Journal of Education 63(3): 9-28.

Livingstone, R. W. 2002. The role of perceived negativity in the moderation of African Americans' implicit and explicit racial attitudes. Journal of Experimental Social Psychology 38(4): 405-413.

Locks, A. M., S. Hurtado, N. A. Bowman and L. Oseguera. 2008. Extending notions of campus climate and diversity to students' transition to college. The Review of Higher Education 31(3): 257-285.

Lorenz, R. 2009. Catholic students and campus change at Loyola University in New Orleans, 19641971. Unpublished master's thesis. University of New Orleans. New Orleans.

Moguerane, K. 2007. Post-apartheid politics of integration at a residential student community in South Africa: A case study on campus. African Sociological Review 11(2): 42-63.

Msomi, S. and W. Shilaho. 2013. Racism still a threat to South Africa's democracy. Centre for the Study of Violence and Reconciliation.

Pearson, A. R., T. V. West, F. J. Dovidio, S. R. Powers, R. Buck, R. Henning. 2008. The fragility of intergroup relations: Divergent effects of delayed audiovisual feedback on intergroup and 
intragroup interactions. Psychological Science 19(12): 1272-1279.

Pettigrew, T. F. 1998. Intergroup contact theory. Annual Review of Psychology 49: 65-85.

Pettigrew, T. F 2008. Intergroup prejudice: Its causes and cures. Actualidades en Psicologia 222(109): $115-124$.

Ponterotto, J. G. and I. Grieger. 2007. Effectively communicating qualitative research. The Counselling Psychologist 35: 404-430.

Ramphele, M. 2008. Laying ghosts to rest: Dilemma of the transformation in South Africa. Cape Town: Tafelberg.

Read, B., L. Archer and C. Leathwood. 2003. Challenging cultures? Student conceptions of 'belonging' and 'isolation' at a post-1992 university. Studies in Higher Education 28(3): 261-277.

Saenz, V. B., S. Hurtado, D. Barrera, D. Wolf and F. Yeung. 2007. First in my family: A profile of firstgeneration college students at four year institutions since 1971. Report from the Higher Education Research Institute and the Foundation for Independent Higher Education. Cooperative Institutional Research Program: UCLA, Los Angeles, CA.

Schofield, J. W., L. M. R. Hausmann, F. Ye and R. L. Woods. 2010. Intergroup friendships on campus: Predicting close and casual friendships between White and African American first year college students. Group Processes \& Intergroup Relations.

Sennet, J., G. Finchilescu, K. Gibson and R. Strauss. 2003. Adjustment of black students at a historically white South African university. Educational Psychology 23(1): 107-116.

Shook, N. J. 2007. Interracial contact: Consequences for attitudes, relationships, and well-being. Unpublished doctoral dissertation, Ohio State University, Columbus.

Smith, W.A, W. R. Allen and L. L. Danley. 2007. 'Assume the position ... You fit the description'. Psychosocial experiences and racial battle fatigue among African American male college students. American Behavioral Scientist 51(4): 551-578.

Solorzano, D., M. Ceja and T. Yosso. 2000. Critical race theory, racial micro-aggressions, and campus racial climate: The experiences of African American college students. Journal of Negro Education: 60-73.

Soto, J. A., N. A. Dawson-Andoh and R. BeLue. 2011. The relationship between perceived discrimination and generalized anxiety disorder among African Americans, Afro Caribbeans, and non-Hispanic whites. Journal of Anxiety Disorders 25(2): 258-265.

Swim, J. K., L. L. Hyers, L. L. Cohen, D. C. Fitzgerald and W. H. Bylsma. 2003. African American college students' experiences with everyday racism: Characteristics of and responses to these incidents. Journal of Black Psychology 29(1): 38-67.

Tredoux, C., J. Dixon, S. Underwood, D. Nunez and G. Finchilescu. 2005. Preserving spatial and temporal dimensions in observational data of segregation. South African Journal of Psychology 35(3): 412-432.

Tropp, L. R. and T. F. Pettigrew. 2005. Relationships between intergroup contact and prejudice among minority and majority status group. Psychological Science 16(12): 951-957.

Tyson, C. 2003. A bridge over troubled water: Social studies, civic education, and critical race theory. In Critical race theory perspectives on social studies: The profession, policies, and curriculum, ed. G. Ladson-Billings, 15-26. Greenwich, CT: Information Age Publishing.

Van der Merwe, J. C. 2009. Communicative-philosophical challenges of managing a male residence at the University of the Free State. Communitas 14: 43-56.

Vincent, L. 2008. 'The limitations of inter-racial contact - Stories from young South Africa'. Ethnic and Racial Studies 31(8): 1426-1451. 